\title{
Quasi-static cyclic testing of two-thirds scale unbonded post-tensioned rocking dissipative timber walls
}

\author{
Francesco Sarti ${ }^{1}$, Alessandro Palermo ${ }^{2}$, Stefano Pampanin ${ }^{3}$
}

\section{Abstract}

Post-tensioning low-damage technologies were first developed in the late 1990s as the main outcome of the U.S. PRESSS (PREcast Seismic Structural System) program coordinated by the University of California, San Diego and culminated with the pseudo-dynamic test of a large scale five-story test building.

The extension of post-tensioned techniques to timber elements led to the development of new structural systems, referred to as Pres-Lam (Prestressed Laminated timber). Pres-Lam systems consist of timber structural frames or walls made of Laminated Veneer Lumber, Glue laminated timber (Glulam) or cross-laminated timber (CLT).

Pres-Lam walls consist of a rocking timber element with unbonded post-tensioned tendons running through the length and attached to the foundation, which provides a centering force to the wall, while energy dissipation is supplied by either internal or external mild steel dissipaters.

Previous tests carried out on post-tensioned timber walls focused on small scale (one-third) specimens with the main objective of evaluating the general response of the system.

The main objective of the experimental program herein presented is the testing and estimating of the response of a series two-third scale post-tensioned walls, with alternative arrangements and combination of dissipaters and post-tensioning, focusing on the construction details adopted in real practice.

The paper first presents a brief discussion on the seismic demand evaluation based on the Displacement-Based Design approach. The construction detailing of the steel dissipater connections, post-tensioning anchorage and shear keys are then presented.

\footnotetext{
${ }^{1}$ Timber Research Engineer, Department of Civil and Natural Resources Engineering, University of Canterbury, Private Bag 8400, 8140, Christchurch, New Zealand

2 Associate Professor, Department of Civil and Natural Resources Engineering, University of Canterbury, Private Bag 8400, 8140, Christchurch, New Zealand

${ }^{3}$ Professor, Department of Civil and Natural Resources Engineering, University of Canterbury, Private Bag 8400, 8140, Christchurch, New Zealand
} 
The main objectives of the experimental program were the investigation of the experimental behaviour of large scale post-tensioned timber walls, with particular focus on the system connection detailing and optimization of post-tensioning anchorage, fastening of the dissipation devices and shear keys. The program consisted of several quasi-static cyclic tests considering different steel dissipater configurations, different levels of post-tensioning initial stress and different dissipater options were considered: both internal and external mild steel tension-compression yield devices were used.

The experimental results showed the performance of post-tensioned timber wall systems which provide high level of dissipation while showing negligible residual displacements and negligible damage to the wall element.

The final part of the paper presents the experimental evaluation of the area-based hysteretic damping for the tested specimens and the results highlight the great influence of the connection detailing of the dissipaters.

\section{Introduction: research background and on-site applications}

Unbonded post-tensioned rocking/dissipative technologies for low-damage seismic resisting systems were first developed by Stone et al. (1995) and further investigated during U.S. PRESSS (PREcast Seismic Structural System) program (Priestley et al., 1999).

Among different solutions developed as part of the research program, the hybrid connection proved to be a very stable and promising solution. The hybrid connection provides a combination of re-centering and dissipative contributions, given by un-bonded post-tensioned tendons and mild steel bars respectively. The cyclic behaviour of the connection can be represented by a "flag-shape" hysteresis where the re-centering and dissipative contributions are represented by a multi-linear elastic and elastic-plastic hysteresis (see Figure 1a).

The hysteresis shape is mainly governed by the re-centering ratio, defined either as the ratio of the post-tensioning contribution to the total moment $\left(\beta=\mathrm{M}_{\mathrm{p} t} / \mathrm{M}_{\mathrm{tot}}\right)$ or to the mild steel moment $\left(\lambda=\mathrm{M}_{\mathrm{pt}} / \mathrm{M}_{\mathrm{s}}\right)$ (Palermo et al., 2005b).
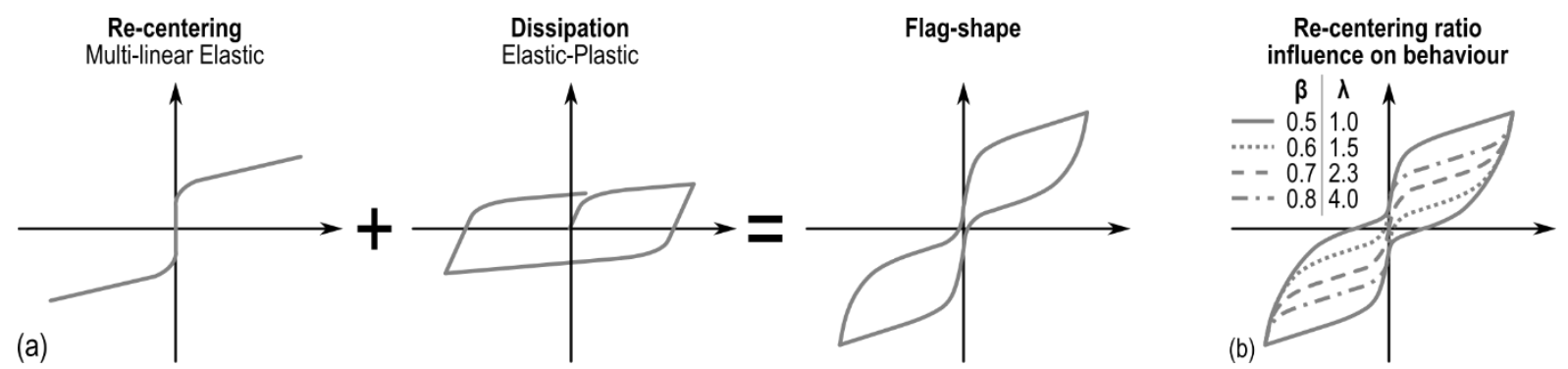

Figure 1. (a) Flag-shape hysteresis. (b) Influence of the re-centering ratio on the hysteretic behaviour. 
As part of the final experimental stage of the PRESSS program a $60 \%$ scale five-story concrete building was constructed and tested under pseudo-dynamic loading. An unbonded post-tensioned precast concrete wall system was used in the test building. The wall system consisted of precast panels coupled with stainless-steel energy-dissipating U-shaped flexural plates (Skinner et al., 1974), welded to embedded plates in adjacent panels. (Priestley et al., 1999).

Further research into the seismic behavior of unbonded post-tensioned precast concrete wall elements was carried out by Rahman et al. (Rahman et al., 2000), Kurama (2000; 2002), Kurama et al. (1999; 2002), Holden et al. (2003) and Aaleti et al. (2009) and included design and experimental testing of unbonded post-tensioned precast concrete walls and coupled walls for seismic resistance. The dissipation contribution in single wall systems was given by mild steel bars. Also viscous damping options were considered at the wall-foundation interface (Kurama, 2000). When coupled walls were considered, the coupling was obtained using post-tensioned rocking/dissipative beams (Kurama et al., 2004).

More recently dynamic test were carried out by Marriott et al. (2008) on unbonded posttensioned rocking/dissipative walls with a combination of hysteretic and viscous dampers in parallel, referred to as Advanced Flag Shape systems. The experimental program consisted of high-speed cyclic, free vibration testing and shake-table tests. The test specimens consisted of mild steel dampers, viscous dampers and a combination of the two dissipating devices. The cyclic behavior of all the post-tensioned walls was found to be very stable. Damage was entirely confined to the external dampers and full static re-centering was achieved (Marriott et al., 2008).

Numerical and analytical studies from Christopoulus et al. (Christopoulos et al., 2002) and Kam et al. (2010) proved that the hybrid system is material independent and different dissipation sources other than mild steel can be used.

The development of engineered wood products such as Laminated Veneer Lumber (LVL), glue laminated timber (Glulam) and Cross-Laminated Timber (CLT) facilitated the extension of post-tensioning techniques to timber elements since they provide adequate strength to resist the significant compressive forces generated from post-tensioned systems. The structural system, referred to as Pres-Lam consists of large LVL (Palermo et al., 2006) or Glulam (Smith et al., 2013) or Cross-Laminated Timber (CLT) (Dunbar et al., 2014) structural frames or walls (Buchanan et al., 2008). Post-tensioned timber walls in particular proved efficient in resisting the seismic action and are the focus of the paper. 
Small-scale specimens of single post-tensioned wall subassemblies were tested with internal and external dissipaters (Palermo et al., 2005a; Palermo et al., 2006; Smith et al., 2007); moreover, coupled post-tensioned walls with U-shape Flexural Plate (UFP) (Kelly et al., 1974) dissipaters were tested by (Iqbal et al., 2007). Coupled post-tensioned walls were also used as a seismic resistant system in the bi-directional quasi static testing of a two-third scale two-story post-tensioned timber building with post-tensioned timber frames in one direction and post-tensioned walls in the other (Newcombe et al., 2010). 

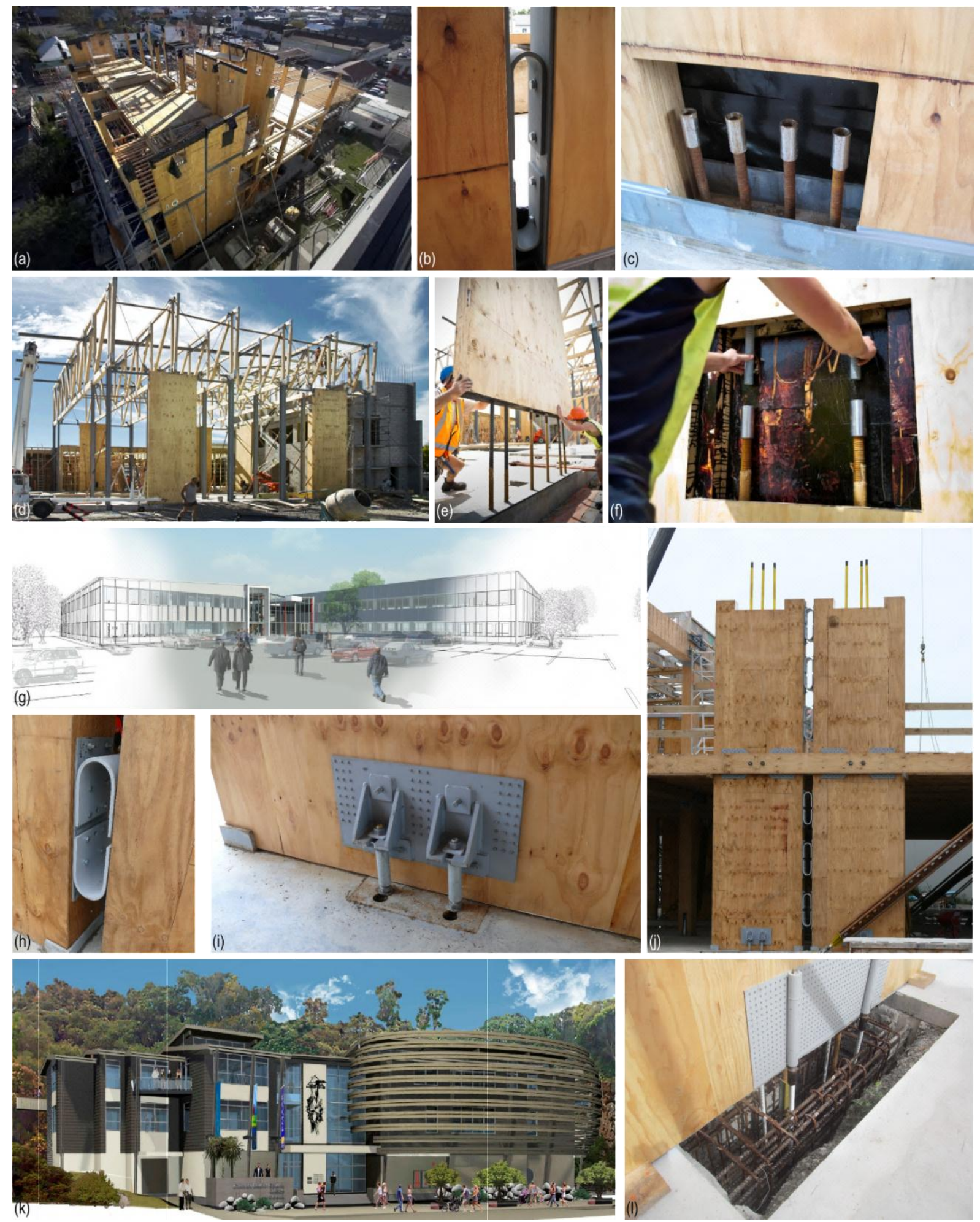

Figure 2. Nelson and Marlborough Institute of Technology (Nelson) (Devereux et al., 2011): (a) aerial view of the construction site; (b) UFP and (c) post-tensioning couplers detail. Carterton Events Centre (Carterton) (Palermo et al., 2012): (d) view of the building under construction; $(e)$ wall base detail under erection; $(f)$ posttensioning coupling. Trimble building (Christchurch): (g) architectural render (Brown et al., 2012); (h) UFP and (i) base dissipater details; ( $j$ ) view of the coupled walls (clo D. Moroder) . Kaikoura District Council Building: (k) architectural render; (l) detail of the dissipaters base connection (c/o A. Buchanan). 
Since 2009 a number of multi-storey timber buildings have been constructed in New Zealand using the Pres-Lam technology.

The Nelson and Marlborough Institute of Technology in Nelson (S 41 16 '33" E 173'17'16", Figure 2a) was the first post-tensioned timber building constructed worldwide; it is a three storey timber building with coupled walls resisting the horizontal actions (Devereux et al., 2011) which uses U-shaped flexural plates (Skinner et al., 1974) as a coupling mechanism and additional dissipative source between the walls (Figure 2b). Figure $2 \mathrm{~d}$ shows the Carterton Events Center (S41 $16^{\prime} 33^{\prime \prime}$ E175 $31^{\circ} 42^{\prime \prime}$ ), a single story building with large timber trusses for carrying the gravity loads and single walls with internal dissipaters resisting the seismic loading (Palermo et al., 2012). The supplemental dissipative reinforcement was cast into the foundation and some debonding was provided as shown in Figure 2e. After the wall was positioned, the post-tensioning bars could be connected through a cut-out in the wall panel (see Figure 2f) and the internal dissipaters epoxy glued in predrilled holes in the timber section.

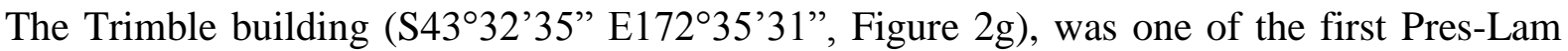
buildings of the rebuild of Christchurch following the September 2010 and February 2011 earthquakes. The building consists of post-tensioned LVL timber frames in one direction, which support the gravity loads of the roof and suspended floor and post-tensioned coupled timber LVL shear walls (Figure 2j) in the orthogonal direction (Brown et al., 2012). The post-tensioned timber walls consist of coupled panels using UFPs (Figure 2h). Additional dissipation is provided by tension-compression yielding mild steel (referred to as fuse-type dissipaters or Plug \& Play devices) dissipaters connected at the base (Figure 2i).

More recently, the Kaikoura District Council building (S42²4'9” E17340'57’, Figure 2k) was designed and is currently under construction. It is a three-story timber building with single walls with fuse-type dissipaters connected at the base as shown in Figure 21.

While past research on post-tensioned timber walls was focused on the general system behaviour and involved experimental research on small scale specimens, this paper presents the first large scale testing program of post-tensioned timber walls. The main objectives of the experimental program were the investigation of the experimental behaviour of large scale post-tensioned timber walls, with particular focus on the system connection detailing and optimization of post-tensioning anchorage, fastening of the dissipation devices and shear keys.

After briefly showing the design of the lateral load resisting system and a simplified section design, the paper shows the construction detailing of the specimen. 
The testing methodology is then presented and the experimental results are discussed in terms of general behaviour as well as detailed design parameters, such as equivalent viscous damping.

\section{Design and detailing of the test specimen}

\section{Seismic design of full-scale prototype}

The prototype case study building was a three storey building with two suspended floors and a lightweight third floor. The building had an approximate plan of $32 \mathrm{~m}$ in the longitudinal direction and $18 \mathrm{~m}$ in the transverse direction with a floor area of approximately $600 \mathrm{~m}^{2}$ per floor. The ground floor level was assumed to be used for retail purposes, level two as office space and level 3 with residential type loadings.

The building was designed using the Christchurch CBD hazard factor $(\mathrm{Z}=0.3)$ and a soil type C according to NZS1170.5 (Standards New Zealand, 2004). For design purposes, the seismic mass of the light-weight top floor was concentrated at the second level, resulting in equal storey seismic weights of $2540 \mathrm{kN}(635 \mathrm{kN}$ per wall).

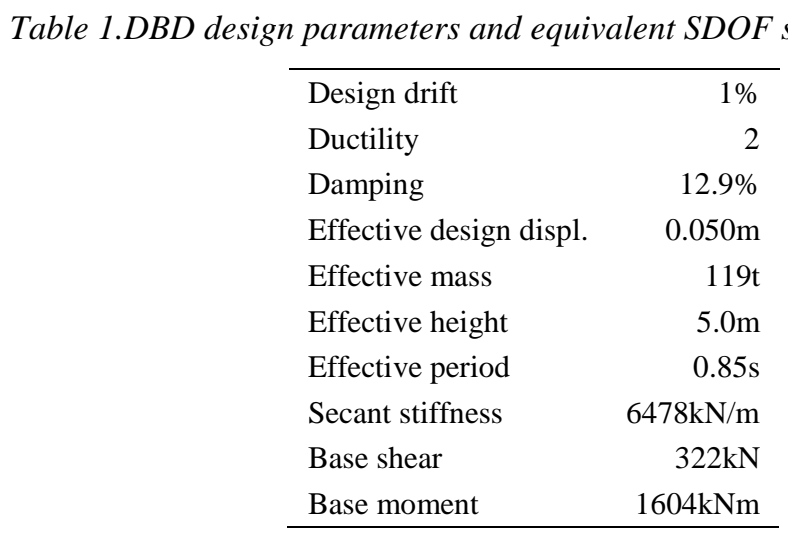

The design was carried out using a Displacement Based Design Procedure, assuming a maximum inter-storey drift of $1 \%$. The key parameters of the equivalent single degree-offreedom system in accordance to a DBD approach (Priestley et al., 2007) are shown in The prototype case study building was a three storey building with two suspended floors and a lightweight third floor. The building had an approximate plan of $32 \mathrm{~m}$ in the longitudinal direction and $18 \mathrm{~m}$ in the transverse direction with a floor area of approximately $600 \mathrm{~m}^{2}$ per floor. The ground floor level was assumed to be used for retail purposes, level two as office space and level 3 with residential type loadings.

The building was designed using the Christchurch CBD hazard factor $(\mathrm{Z}=0.3)$ and a soil type C according to NZS1170.5 (Standards New Zealand, 2004). For design purposes, the 
seismic mass of the light-weight top floor was concentrated at the second level, resulting in equal storey seismic weights of $2540 \mathrm{kN}(635 \mathrm{kN}$ per wall).

Table 1 and the design base shear and moment are $322 \mathrm{kN}$ and $1604 \mathrm{kNm}$ per wall respectively using the displacement design spectrum shown in Figure 3.

The specimen design was performed using a scaled shear/moment demand (according to a constant density approach):

$$
\begin{aligned}
& V_{2 / 3}=\lambda^{2} V_{b}=(2 / 3)^{2} \cdot 329 k N=143 k N \\
& M_{2 / 3}=\lambda^{3} M_{b}=475 k N m
\end{aligned}
$$

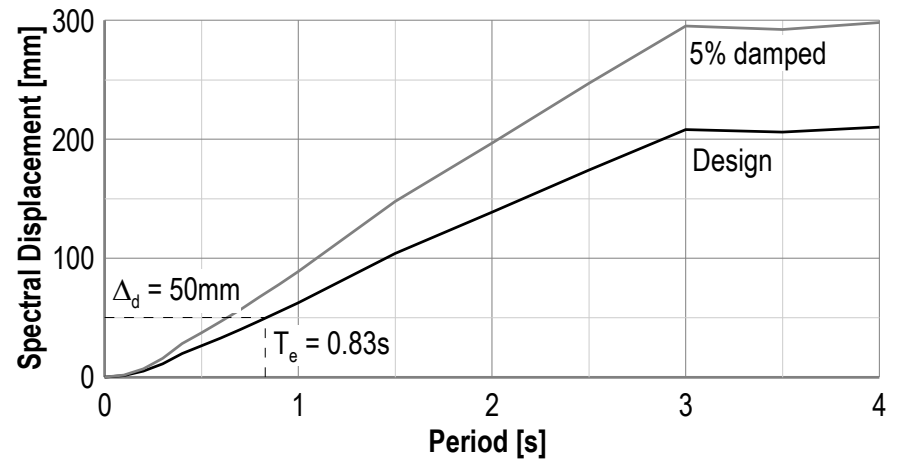

Figure 3. Pseudo displacement design spectrum, soil type D, $Z=0.3$ (Standards New Zealand, 2004).

To resist the scaled design loads, the single wall specimen had two high-strength $32 \mathrm{~mm}$ posttensioning bars (Macalloy, 2007) stressed to a total initial post-tensioning force of $400 \mathrm{kN}$ $\left(30 \% \mathrm{f}_{\mathrm{py}}, 24 \% \mathrm{f}_{\mathrm{pu}}\right)$ and $8 \mathrm{D} 14 \mathrm{~mm}$ mild steel dissipaters. A summary of the material structural properties is shown in Table 2.

Table 2. Material properties.

\begin{tabular}{lcc}
\hline \multicolumn{3}{c}{ Laminated Veneer Lumber } \\
\hline Modulus of Elasticity & $\mathrm{E}_{\mathrm{t}}$ & $11 \mathrm{GPa}$ \\
$\begin{array}{l}\text { Compression strength parallel } \\
\text { to the grain }\end{array}$ & $\mathrm{f}_{\mathrm{ct}}$ & $45 \mathrm{MPa}$ \\
\hline
\end{tabular}

\begin{tabular}{lrr}
\hline \multicolumn{3}{c}{ Post-tensioning steel } \\
\hline Yield stress & $\mathrm{f}_{\mathrm{py}}$ & $835 \mathrm{MPa}$ \\
Ultimate stress & $\mathrm{f}_{\mathrm{pu}}$ & $1030 \mathrm{MPa}$ \\
Modulus of & $\mathrm{E}_{\mathrm{p}}$ & $170 \mathrm{GPa}$ \\
Elasticity & & \\
\hline
\end{tabular}

\begin{tabular}{lcr}
\hline \multicolumn{3}{c}{ Mild steel } \\
\hline Yield stress & $\mathrm{f}_{\mathrm{ys}}$ & $400 \mathrm{MPa}$ \\
Ultimate stress & $\mathrm{f}_{\mathrm{ys}}$ & $500 \mathrm{MPa}$ \\
Ultimate strain & $\%$ & 9.0 \\
Modulus of & $\mathrm{E}_{\mathrm{s}}$ & $200 \mathrm{GPa}$ \\
Elasticity & & \\
\hline
\end{tabular}

\section{Testing specimens detailing}

\section{Wall optimized section and post-tensioning anchorage}

The timber section of the specimen (Figure $4 \mathrm{a}$ ) was $0.189 \mathrm{~m} \times 1.57 \mathrm{~m}$ and made of standard $63 \mathrm{~mm}$ thick Laminated Veneer Lumber (LVL) profiles chosen to optimize the section. The voids created for the post-tensioning bars were reduced to a minimum to maximize the bearing area for the post-tensioning anchorage at the top of the wall.

Figure $4 \mathrm{~b}$ shows the wall before erection, highlighting the detail of the anchorage plate. A Grade300 60mm thick steel plate was used. 


\section{Shear key}

Although a large amount of friction was expected to be developed at the base of the wall due to the high compressive forces, Appendix B of NZS3101:2006 (Standards New Zealand, 2006) does not permit resisting of shear by friction, differently from ACI 318-11 (ACI, 2011); therefore, external shear keys were introduced to provide more robustness to the system and prevent sliding both in the in-plane and out-of plane directions. $40 \mathrm{~mm}$ thick plates were used to prevent in-plane sliding and thinner $6 \mathrm{~mm}$ plates were welded on the sides to prevent out-of-plane displacements. To allow for a construction tolerance, slotted holes were drilled for connecting the shear key to the foundation. The detail of the shear key is shown in Figure 4c.

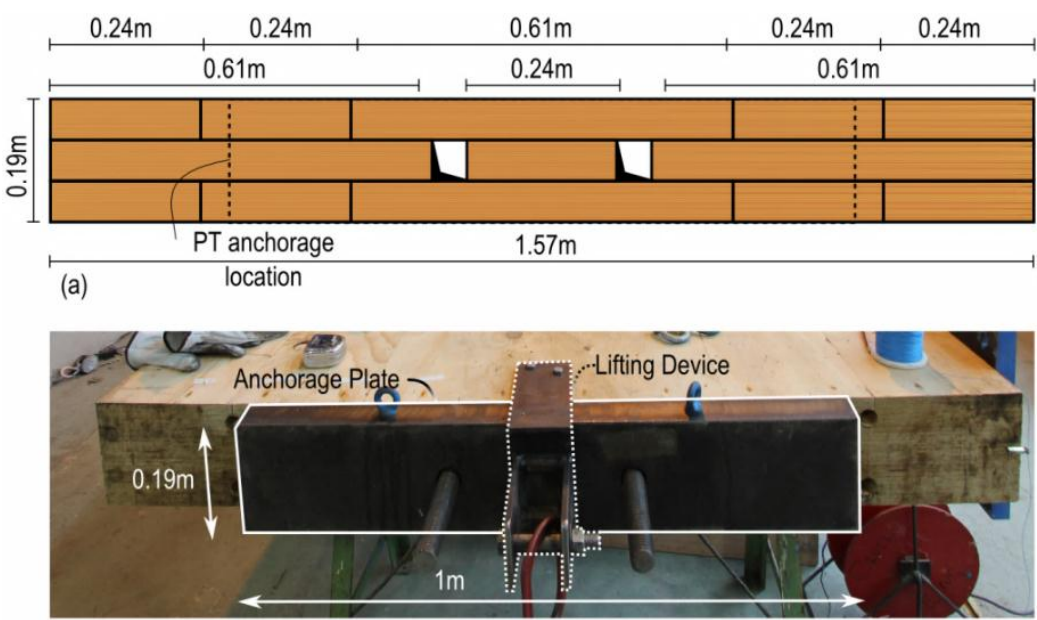

1000

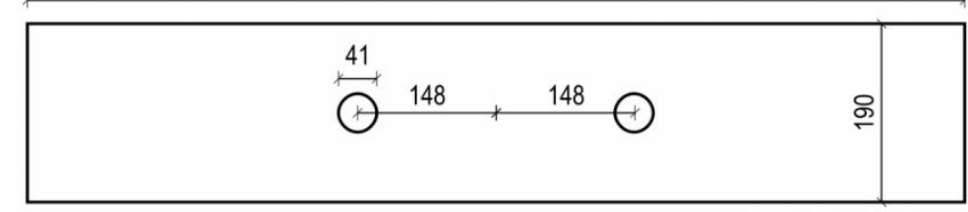

(b)
*Dimensions in millimiters

(c)

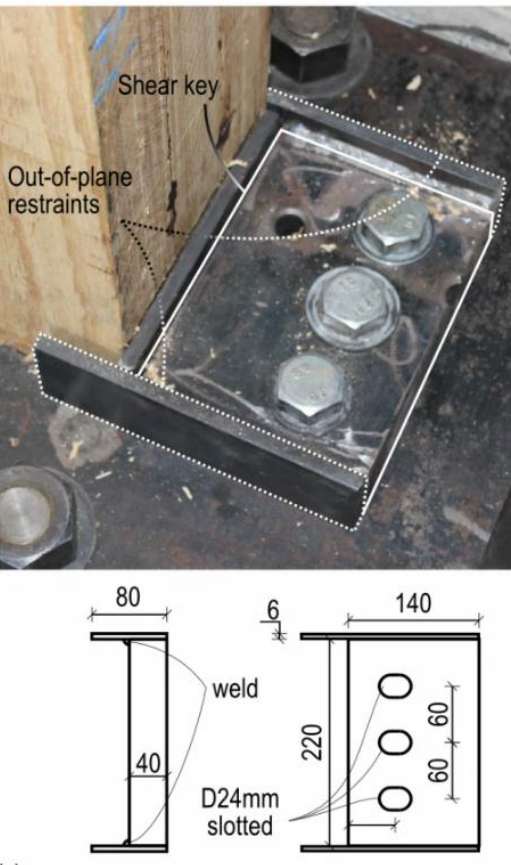

Figure 4. (a) Wall cross-section. (b) Post-tensioning plate detail; (c) shear key.

\section{Dissipaters}

When using external dissipation devices, the dissipater-to-wall connection must be carefully detailed in order to provide the required strength, as well as to limit the deflection associated with the connection stiffness. The latter can delay the activation of the dissipaters reducing the system's moment and dissipation capacity at the design target drift. Common practice in timber engineering is the use of metallic fasteners such as screws, bolts or timber rivets. The latter represents a good solution for this type of application, since they enable a connection with high stiffness, with no significant overdesign. Figure 5 shows the details of the connection. A $6 \mathrm{~mm}$ thin plate was connected to the wall element using $90 \mathrm{~mm}$ long timber 
rivets. A $20 \mathrm{~mm}$ thick plate was welded to the riveted plate providing the connection setup for the dissipaters.

The dissipation device were tension-compression yield (TCY) fuse-type dissipate rand consisted of a mild steel rebar, milled down to a reduced diameter to concentrate the damage within a fuse (gauge) length, whilst maintaining the connecting parts in the elastic range (Marriott et al., 2008). To avoid buckling, a restraining system made of a circular hollow section (CHS60.3×3.6) filled with epoxy was used. Extensive experimental testing on this type of dissipater was carried out by Sarti et al. (2013) and the device was also used in posttensioning concrete applications in the past (Marriott et al., 2008).

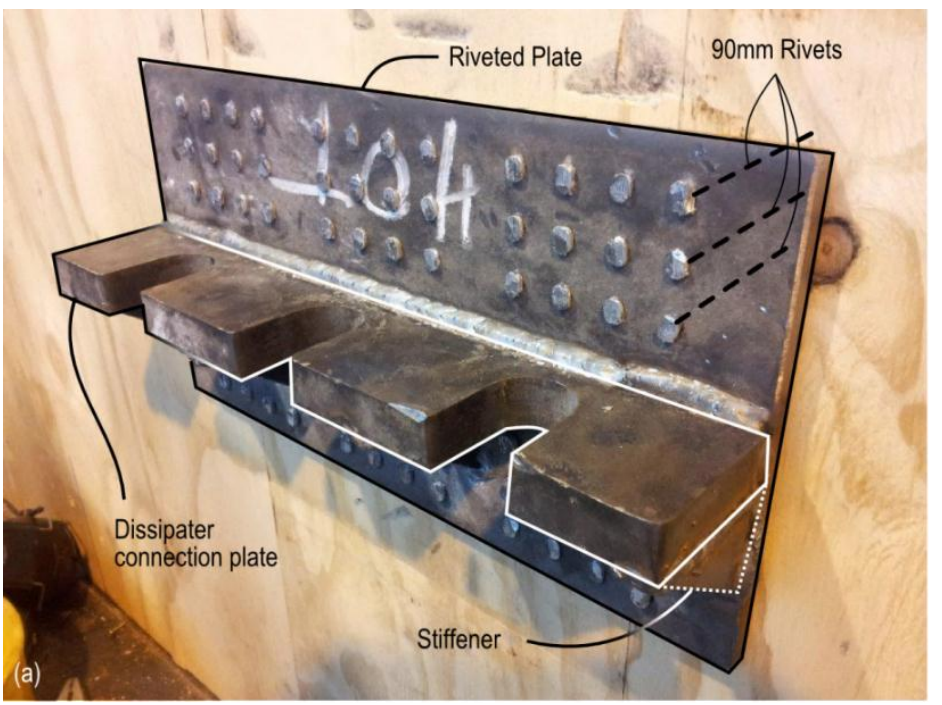

M30 metric thread

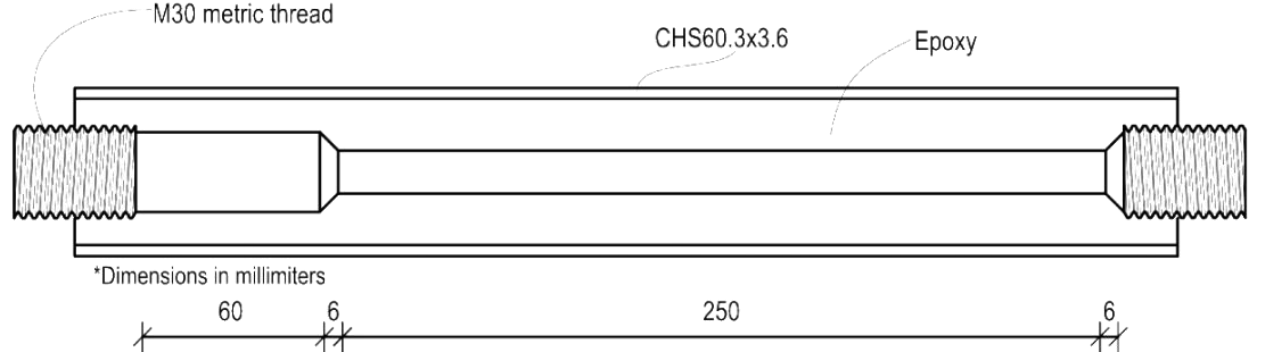

Figure 5. Fuse-type dissipater connection: (a) detail of the connection; (b) final setup; (c) details of the dissipater.

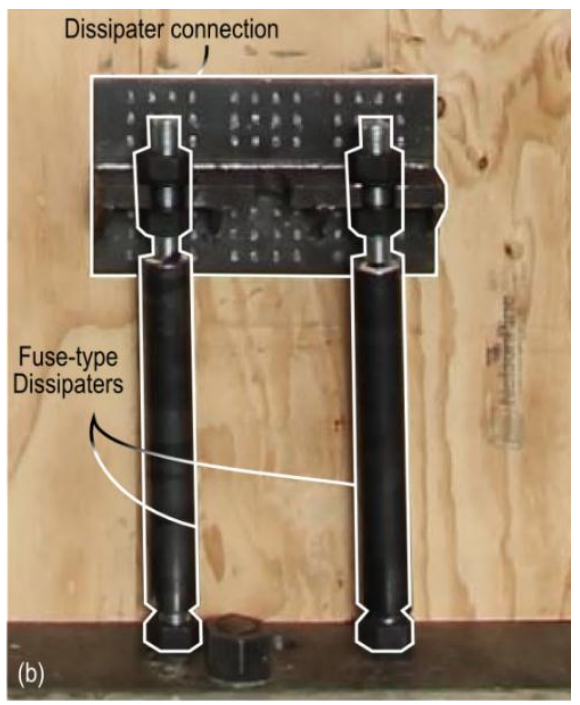

(c)

Internal dissipaters were used as well and they were glued in the timber section using epoxy resin. $26 \mathrm{~mm}$ diameter holes were drilled in the wall section in order to provide the positioning tolerance. The holes were drilled $800 \mathrm{~mm}$ deep into the section providing the required embedment length for epoxied bars, in accordance with Buchanan (2007). This also provided for the unbonded length of $300 \mathrm{~mm}$. For the internal dissipation devices a threaded bar was used and gauged down to a fuse diameter of $14 \mathrm{~mm}$ (same as the external dissipaters). The threaded portions allowed the connection of the dissipater in the foundation plate via 
threaded holes (see the foundation details below) and also the bonding surface inside the timber section. Figure 6 shows the positioning of the holes and the dissipater details.

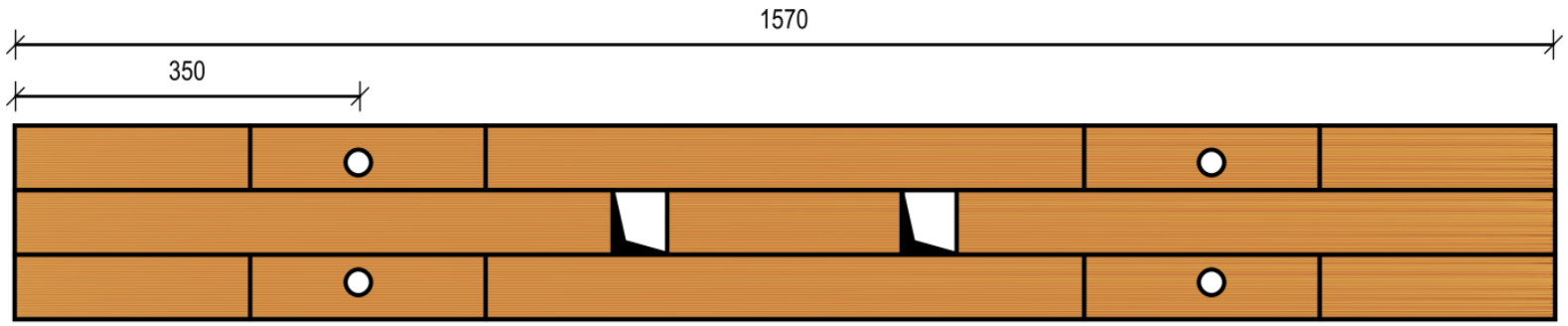

*Dimensions in millimiters

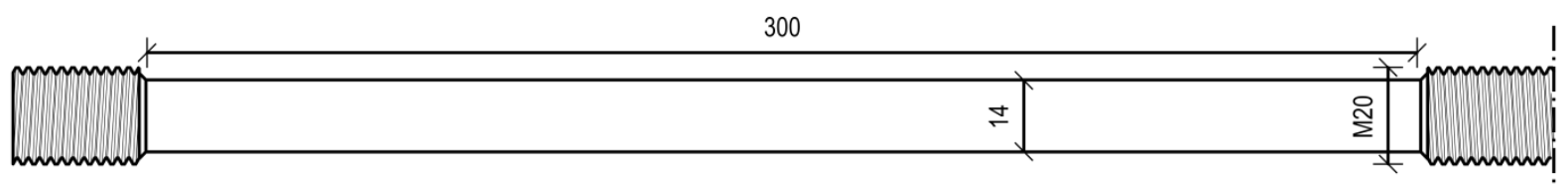

Figure 6. Internal dissipaters' location and details.

\section{Foundation details}

A reinforced concrete foundation was used to support the wall. The concrete block was $0.53 \mathrm{~m}$ deep, $0.76 \mathrm{~m}$ wide and $2.66 \mathrm{~m}$ long. Several ducts were created in the foundation to allow the connection to the strong floor with anchoring bolts. A pocket was created in the bottom part of the concrete block to accommodate the post-tensioning anchorage devices in the foundation.

A $32 \mathrm{~mm}$ thick steel plate was positioned on the top of the foundation to create an even surface for the wall base as well as the necessary threaded holes for the connections. The details of the foundation are shown in Figure 7.
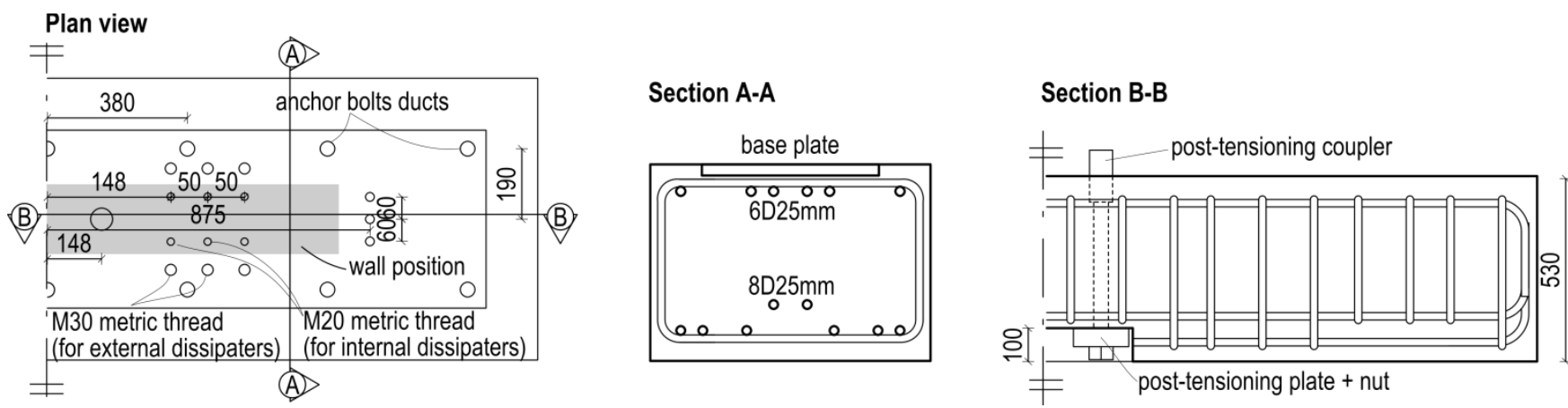

Figure 7. Concrete block foundation details.

\section{Testing methodology}

The testing schedule was developed starting from the reinforcement design presented in previous sections. The reinforcement configuration was varied in terms of the initial posttensioning force applied and mild steel reinforcement layout. Several tests on the posttensioned only configuration specimens were carried out, varying the initial post-tensioning 
forces from $200 \mathrm{kN}$ to $400 \mathrm{kN}$ and $600 \mathrm{kN}$. Those post-tensioning forces were chosen to provide the post-tensioned only experimental curve to compare to the hybrid specimens.

Hybrid tests were performed with different numbers of dissipaters to assess the influence of the re-centering ratio. The testing schedule is reported in Table 3.

Table 3.Post-tensioned walls testing schedule.

\begin{tabular}{cccc}
\hline Test ID & PT Initial & Dissipaters & $\begin{array}{c}\text { Re-centering } \\
\text { Ratio }\left(\boldsymbol{\beta}=\mathbf{M}_{\mathbf{p t}} / \mathbf{M}_{\text {tot }}\right)\end{array}$ \\
\hline S200 & $200 \mathrm{kN}$ & $\mathrm{n} / \mathrm{a}$ & 1.0 \\
$\mathrm{~S} 400$ & $400 \mathrm{kN}$ & $\mathrm{n} / \mathrm{a}$ & 1.0 \\
$\mathrm{~S} 600$ & $600 \mathrm{kN}$ & $\mathrm{n} / \mathrm{a}$ & 1.0 \\
$\mathrm{~S} 400-8$ & $400 \mathrm{kN}$ & $8 \mathrm{D} 14 \mathrm{~mm}$ & 0.6 \\
$\mathrm{~S} 400-4$ & $400 \mathrm{kN}$ & $4 \mathrm{D} 14 \mathrm{~mm}$ & 0.7 \\
$\mathrm{~S} 600-4$ & $600 \mathrm{kN}$ & $4 \mathrm{D} 14 \mathrm{~mm}$ & 0.8 \\
S600-4i & $600 \mathrm{kN}$ & $4 \mathrm{D} 14 \mathrm{~mm}$ (internal) & 0.8 \\
\hline
\end{tabular}

The test setup is shown in Figure 8. The wall was loaded simulating a triangular distribution of forces accordingly to the case study design which assumes the top floor mass concentrated at the second level. The applied point loads were achieved using a $2 \mathrm{~m}$ long distribution beam (250UC89.5) which was linked to the wall and the actuator through steel hinges. The centreto-centre distance between the top and bottom pin hinges was $2 \mathrm{~m}$ and the pin hinge connecting the distribution beam to the hydraulic actuator was positioned at $0.64 \mathrm{~m}$ from the top pin hinge.

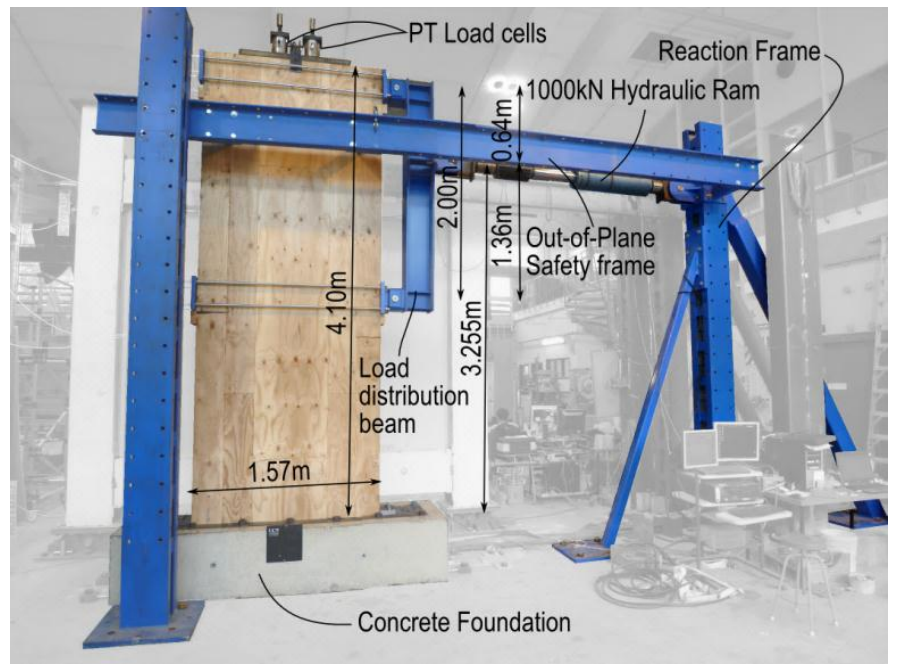

Figure 8. Test setup.

The load was applied by a $1000 \mathrm{kN}$ hydraulic actuator mounted at the height of $3.7 \mathrm{~m}$ from the strong floor ( $3.2 \mathrm{~m}$ from the bottom of the wall).

For safety purposes the out-of-plane displacement of the wall was restrained by sliders consisting of small steel plates with a rubber wheel bolted on 300PFC (Parallel Flange Channel) profiles. To provide support for the PFC profiles, an additional column was 
connected on the front side of the test setup (see Figure 9a), while on back of the specimen an existing column from a different test setup was used.

The quasi-static displacement loading consisted of sequential displacement-controlled cycles according to ACI ITG-5.1-07 protocol (ACI Innovation Task Group 5, 2008): the maximum displacement of the first three cycles did not exceed $60 \%$ of the design displacement $(0.040 \mathrm{~m})$; the maximum displacement of the subsequent cycles was between 1.25 and 1.5 times the previous maximum displacement. A maximum drift of $2 \%$ was imposed and that corresponds to the Maximum Credible Event (MCE) scenario according to a capacity demand spectrum method (Chopra et al., 1999).

\section{Instrumentation and key design parameters}

The experimental test was a displacement controlled setup and the top drift was measured using a rotary potentiometer ( $\mathrm{D}$ in Figure 9a). The applied load was recorded through the $1000 \mathrm{kN}$ load cell (LC in Figure 9a) mounted on the hydraulic actuator.

The post-tensioned forces were monitored by two $1000 \mathrm{kN}$ load cells at the top of the wall (PT1 and PT2).
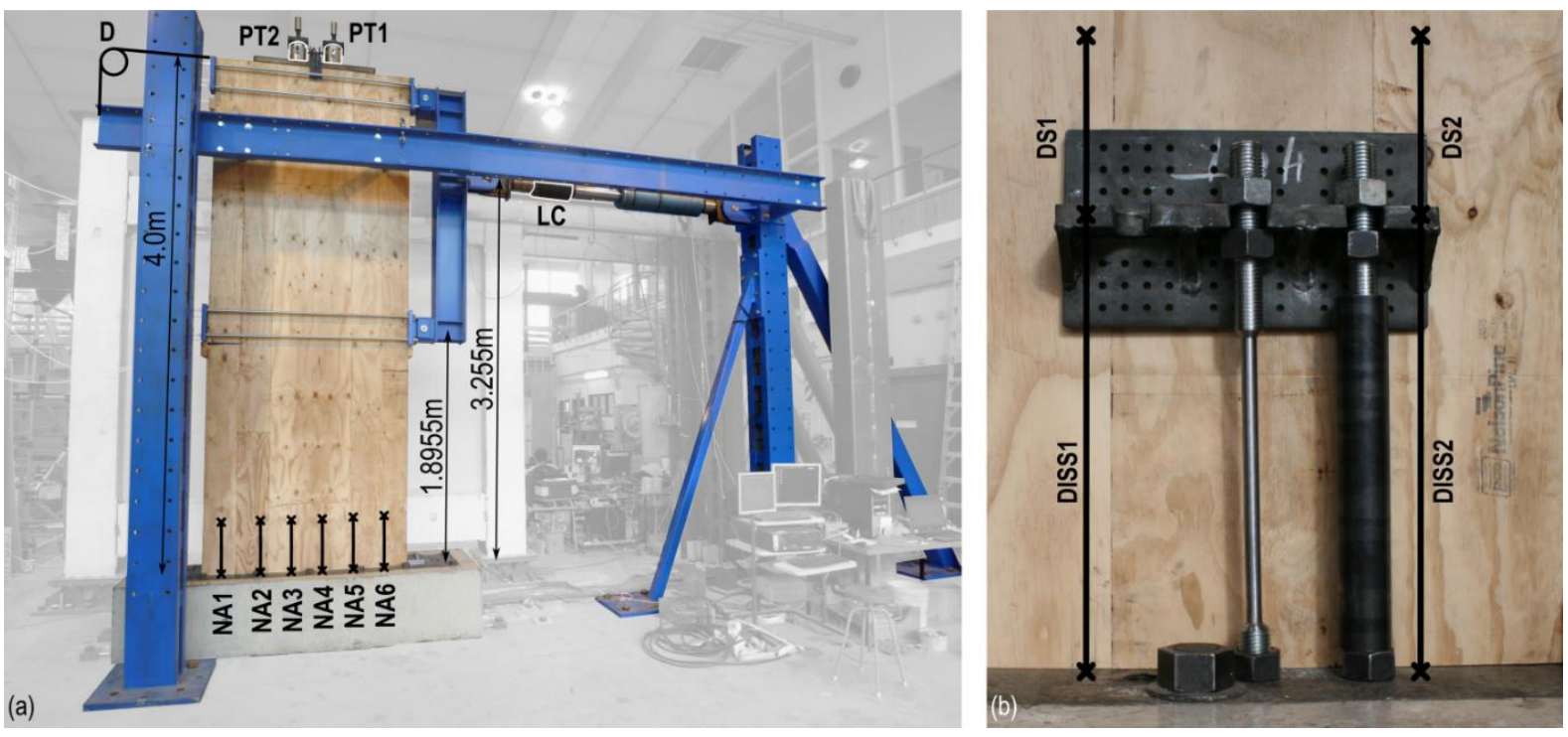

Figure 9. (a) Instrumentation setup for overall response and (b) instrumentation for detailing.

A key design and response parameter of a post-tensioning rocking connection is the neutral axis depth. In fact, during the rocking mechanism, the structural wall, rather than displaying a rigid body motion pivoting around the corners, develops, as per any deformable body, a compressive region within the rocking interface.

The neutral axis depth was measured using six spring loaded potentiometers (NA1 to NA6) fixed at the wall base. A linear function was used to fit the potentiometer readings. The 
neutral axis depth corresponded to the zero of the linear fitting function and the connection rotation (gap opening) was the slope of such function.

Figure 10a shows neutral axis depth variation versus the connection rotation from the analytical formulas below and Figure 10b gives an indication of the nomenclature. As soon as decompression occurs (i.e. non-zero connection rotation) the neutral axis, c, decreases causing an increase of post-tensioning force in the tendons. The main parameter affecting the variation of the neutral axis depth is the total compressive force acting on the section, given by the tensile forces in the post-tensioning bars, as well as the forces developed in the dissipaters. For higher compressive forces the minimum neutral axis values value is bigger.

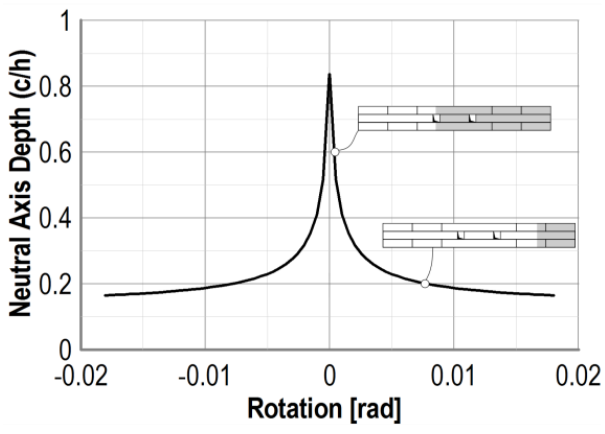

(a)

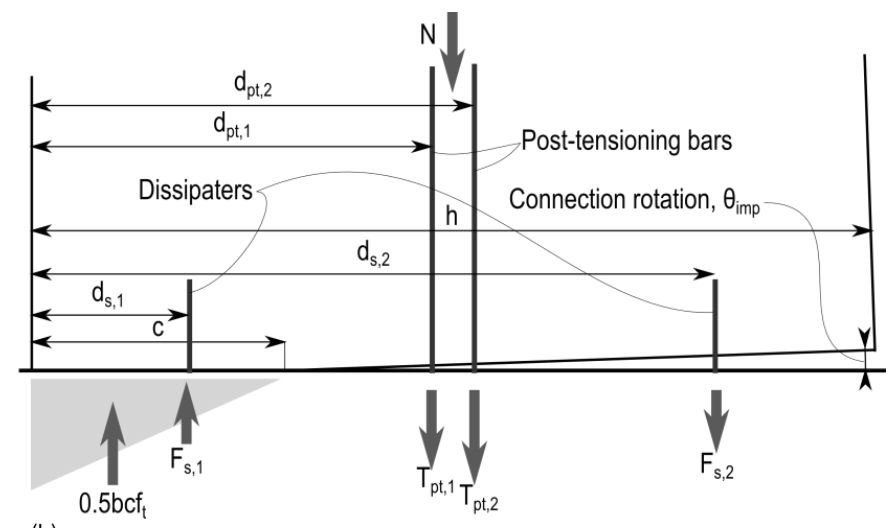

(b)

Figure 10. Neutral axis (a) evaluation and (b) nomenclature

Using the neutral axis depth from the experimental results, the stress in the timber compressive area can be evaluated. The timber compressive stress $\left(\mathrm{f}_{\mathrm{t}}\right)$ can be calculated assuming a triangular distribution of stress (see Figure 10b) as:

$$
f_{t}=\frac{N+\sum T_{p t, i}+\sum F_{s, i}}{0.5 b c} \rightarrow N+\sum T_{p t, i}+\sum F_{s, i}-C_{t}=0
$$

Where $\mathrm{b}$ is the section width, $\mathrm{c}$ the neutral axis depth, $\mathrm{N}$ the axial force from gravity load (if present), $T_{p t, i}$ is the post-tensioning force of the $\mathrm{i}$-th tendon (given in Equation (3)) and $\mathrm{F}_{\mathrm{s}, \mathrm{i}}$ is the force of the i-th dissipater layer (given in Equation (4)).

An elastic relationship was used in Equation (2) since the timber section usually remains elastic, but if plastic deformation occurs an elastic-perfectly plastic relationship was used.

In general, the dissipaters contribution in Equation (2) can be neglected since for symmetric reinforcement the tension and compression dissipaters have both yielded and the summation of the forces is approximately zero. 


$$
T_{p t, i}=T_{p t, \text { initial }}+\Delta \varepsilon_{p t, i} E_{p t} A_{p t, i} ; \Delta \varepsilon_{p t, i}=\frac{\theta_{i m p}\left(d_{p t, i}-c / 3\right)}{l_{u b}}
$$

Where $\mathrm{T}_{\mathrm{pt} \text {,initial }}$ is the initial post-tensioning force in each tendon, $\Delta \varepsilon_{\mathrm{pt}, \mathrm{i}}$ the strain increase in the $\mathrm{i}$-th post-tensioning tendon, $\theta_{\mathrm{imp}}$ the connection rotation, $\mathrm{d}_{\mathrm{pt}, \mathrm{i}}$ is the edge distance of the $\mathrm{i}$ th tendon, $1_{\mathrm{ub}}$ the unbonded length, $\mathrm{E}_{\mathrm{pt}}$ the post-tensioning steel modulus of elasticity, $\mathrm{A}_{\mathrm{pt}, \mathrm{i}}$ the i-th tendon cross-sectional area.

When dissipaters are used as supplemental reinforcement, the forces in the dissipaters, $\mathrm{F}_{\mathrm{s}, \mathrm{i}}$, shall be taken into account in the force equilibrium:

$$
F_{s, i}=A_{\mathrm{s}, i} \begin{cases}E_{s} \varepsilon_{s, i} & \text { if } \varepsilon_{s, i}<\varepsilon_{s y} \\ f_{s y}\left[1+r\left(\frac{E_{s} \varepsilon_{s, i}}{f_{s y}}-1\right)\right] & \text { if } \varepsilon_{s, i}<\varepsilon_{s y}\end{cases}
$$

Where $A_{s, i}$ is the $i$-th dissipater cross-section area, $E_{s}$ the steel modulus of elasticity, $f_{s}$ the mild steel yield strength, $r$ the post-yield stiffness ratio and $\varepsilon_{\mathrm{s}, \mathrm{i}}$ the $\mathrm{i}$-th dissipater strain given as:

$$
\varepsilon_{s, i}=\frac{\Delta_{s, i}}{l^{\prime}{ }_{u b}} ; \Delta_{s, i}=\theta_{i m p}\left(d_{s, i}-c / 3\right)
$$

Where $\Delta_{\mathrm{S}, \mathrm{I}}$ is the dissipater's displacement, $\mathrm{d}_{\mathrm{s}, \mathrm{i}}$ the edge distance of the $\mathrm{i}$-th tendon, $1_{\mathrm{ub}}$ the unbonded length of the $\mathrm{i}$-th dissipater.

When using external dissipaters some type of connection to the structural element must be provided. Although over-designed for strength, the flexibility of the dissipaters' connections must be taken into account when assessing the behaviour of post-tensioned rocking sections. A set of potentiometers were used to measure the relative displacement between the riveted connection plate and the wall and to measure the net displacement of the dissipaters. When more than one dissipater was connected through the same plate the loading pattern on the connection was eccentric, so the potentiometers were positioned at the edges of the connection plate to capture the plate's rotation (see Figure 9b). Two sets of LVTDs were used: DISS1 and DISS2 (see Figure 9b) captured the net displacement of the dissipaters, while DS1 and DS2 (see Figure 9b) measured the relative slip occurring between the connection plate and the wall.

The average strain of the dissipaters, $\varepsilon_{\mathrm{s}, \mathrm{n}}$, used in the experimental test setup was evaluated as: 
$\varepsilon_{s, n}=\frac{\Delta_{D I S S n}}{l_{u b}^{\prime}}$

Where $\Delta_{\text {DISSn }}$ is the potentiometer reading of either DISS1 or DISS2 and l' ub is the fuse length of the dissipater $(250 \mathrm{~mm})$.

The elastic displacement contribution of the riveted connection can have a major effect on the overall system behaviour since it may delay the activation of the dissipaters until higher drift, thus affecting the overall ductility and energy dissipation. The influence of this parameter is assessed and discussed in the final part of the paper.

\section{Test results}

\section{Pure post-tensioned rocking}

The test results are discussed with reference to the different reinforcement configurations. The experimental program started with tests on post-tensioned only configurations. Since no dissipation device was used in this phase as supplemental reinforcement, the behaviour was expected to be non-linear elastic as typical of a rocking and re-centering system.

In a pure post-tensioned rocking solution no connection rotation is occurring until the decompression moment, $\mathbf{M}_{\mathrm{dec}}$, is reached, where $\mathrm{M}_{\mathrm{dec}}$ is given by;

$$
\frac{M_{d e c}}{S_{t}}-\frac{N+\sum T_{p t, i}}{A_{t}}=0 \rightarrow M_{d e c}=\left(N+\sum T_{p t, i}\right) \frac{S_{t}}{A_{t}}
$$

Where $S_{t}$ and $A_{t}$ are the timber section modulus and cross-sectional area respectively. For rectangular sections $S_{t} / A_{t}=h / 6$, where $h$ is the section depth.

As shown in the moment-rotation loop (Figure 11b), before the decompression moment is achieved, no rotation occurs at the base connection. The force-displacement loop in Figure 11a shows that the system flexibility is given by the elastic bending and shear deflections of the cantilever wall (i.e. fully fixed base) before the gap opens.

Once past the decompression point, the wall displayed the typical non-linear elastic behaviour up to $1.5 \%$ drift. For higher drifts some minor hysteresis was displayed in the moment-rotation for all the post-tensioned only specimens (see Figure 11). This was assumed to be caused by the minor post-tensioning losses possibly due to two main factors; (i) minor plastic deformations occurring on the surface of the bearing plates due to highly concentrated stresses on the reduced area of the washer; (ii) the yielding stress (835MPa) of manufacturer's specifications is defined as $0.1 \%$ proof stress; therefore, small plastic 
deformations are anticipated. This was confirmed by the increased post-tensioning losses in specimen S600 in Figure 11 (black line).

Post-tensioning losses at the end of the test for each of the three specimens were $42 \mathrm{kN}, 40 \mathrm{kN}$ and $67 \mathrm{kN}(21 \%, 10 \%$ and $11 \%$ of the initial post-tensioning force) for the $200 \mathrm{kN}, 400 \mathrm{kN}$ and $600 \mathrm{kN}$ initial post-tensioning forces respectively.

More significant degradation behaviour was observed for specimen S600 where it is assumed that the effect was caused by both the minor plastic deformation of the post-tensioning bars and by some inelastic deformation of the timber section at the base connection. Timber plastic deformation was observed only for the specimens with the highest post-tensioning stress levels (S600), whilst the compressive stresses for the other specimens remained within the elastic limit.

Figure 11c,d also shows the typical post-tensioning force and neutral axis depth variation. As soon as the gap opens between wall and foundation, the tendon elongation causes an increase in the post-tensioning force.

As expected, an increase of post-tensioning force led to higher capacity of the specimens, but the neutral axis depth was not significantly influenced by the increased axial load reaching approximately $25 \%$ of the section depth at design drift.
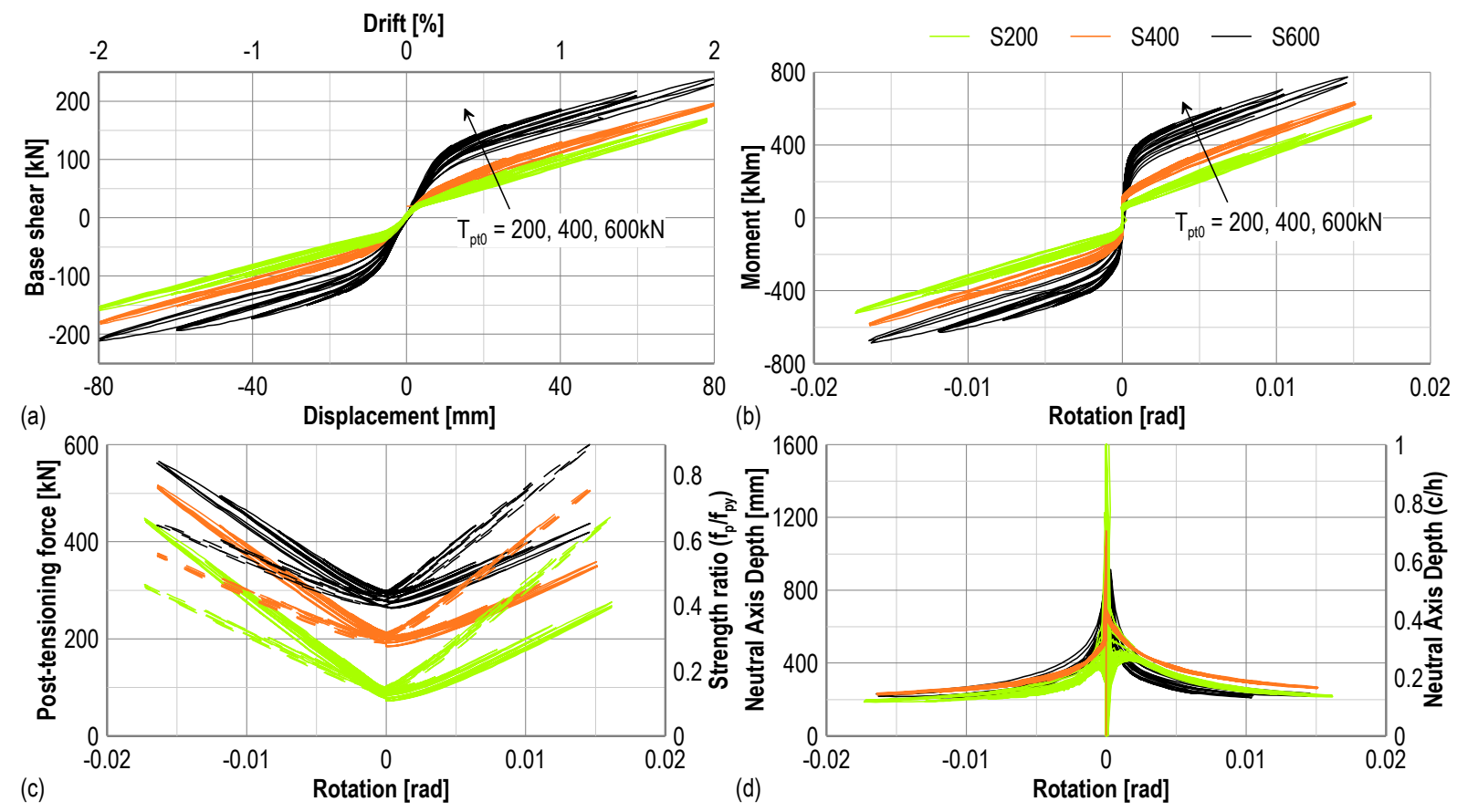

Figure 11. Single wall post-tensioned only experimental results. (a) force-displacement; (b) moment-rotation;

(c) post-tensioning force-rotation and $(d)$ neutral axis depth-rotation. 


\section{Dissipative post-tensioned rocking}

In the second phase of the experimental program, hybrid (i.e. post-tensioned and dissipative) configurations were tested. This was achieved by adding some dissipating devices with different configurations and reinforcing ratios (re-centering ratios, $\beta=\mathrm{M}_{\mathrm{pt}} / \mathrm{M}_{\mathrm{tot}}, 0.6,0.7$ and 0.8). Several tests were carried out using the external mild steel type dissipaters and finally the equivalent configuration as S600-4 was tested using internal dissipaters.

The dissipaters were positioned at $350 \mathrm{~mm}$ from the either edge of the wall. This design choice was made to optimize the system behaviour accounting for the different characteristics of the dissipater response. The dissipater would give a greater moment contribution when positioned at the wall edges; however, the strain demand is much greater and as a result the dissipaters would need to have a longer fuse length to prevent premature ultimate tensile failure. Additionally a longer fuse length corresponds to a higher slenderness and this would increase the buckling propensity of the dissipater.

The hybrid specimen S400-8 experimental results are shown in Figure 12a. The results display a flag-shaped hysteresis, despite full re-centering not being accomplished. In fact, the solution was designed with a re-centering ratio $\beta=\mathrm{M}_{\mathrm{p} t} / \mathrm{M}_{\mathrm{tot}}=0.6(60 \%$ re-centering and $40 \%$ dissipative contribution respectively) at design drift (i.e. 1\%), the experimental results show a re-centering ratio of about 0.5 . This decreased value was due to over-strength in the mild steel which developed higher yielding stress than the nominal value considered in the design phase. Also, increased compressive forces are observed in the dissipaters due to isotropic strain hardening, which were not accounted for in the section design. As a result, a residual drift of $0.6 \%$ was observed after testing.

Some stiffness degradation was observed as well and that was due to some flexibility of the dissipater's connection as well as the ratcheting behaviour of the dissipaters. This effect is further discussed later in the paper.

The hybrid specimen S600-4 was designed to achieve the same capacity as the S400-8 specimen but with a different re-centering/dissipative ratio $(\beta=0.8)$. The flag-shape hysteresis was thinner due to the reduced dissipation contribution. Furthermore, the same stiffness degradation was present, but the effect was reduced because of the lower force acting on the connection. No residual deformations were observed for this configuration.

The same configuration as the S600-4 specimen was tested with internal dissipaters (S600-4i) and the results are shown in Figure 12d. 
The specimen shows very similar results to the equivalent solution with external dissipaters up to the design drift level of $1 \%$. With subsequent amplitude cycles (up to $1.5 \%$ ) the internal dissipaters fractured and in the final cycles at 2\% drift (MCE level) the hysteresis loop showed the elastic bi-linear trend of the post-tensioned only solution, still maintaining a substantial residual capacity, corresponding to the full contribution of the post-tensioned steel.
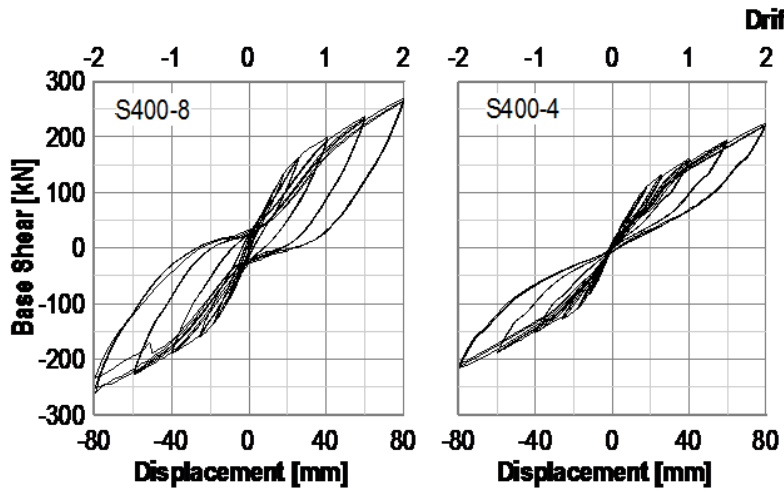

Drift [\%]
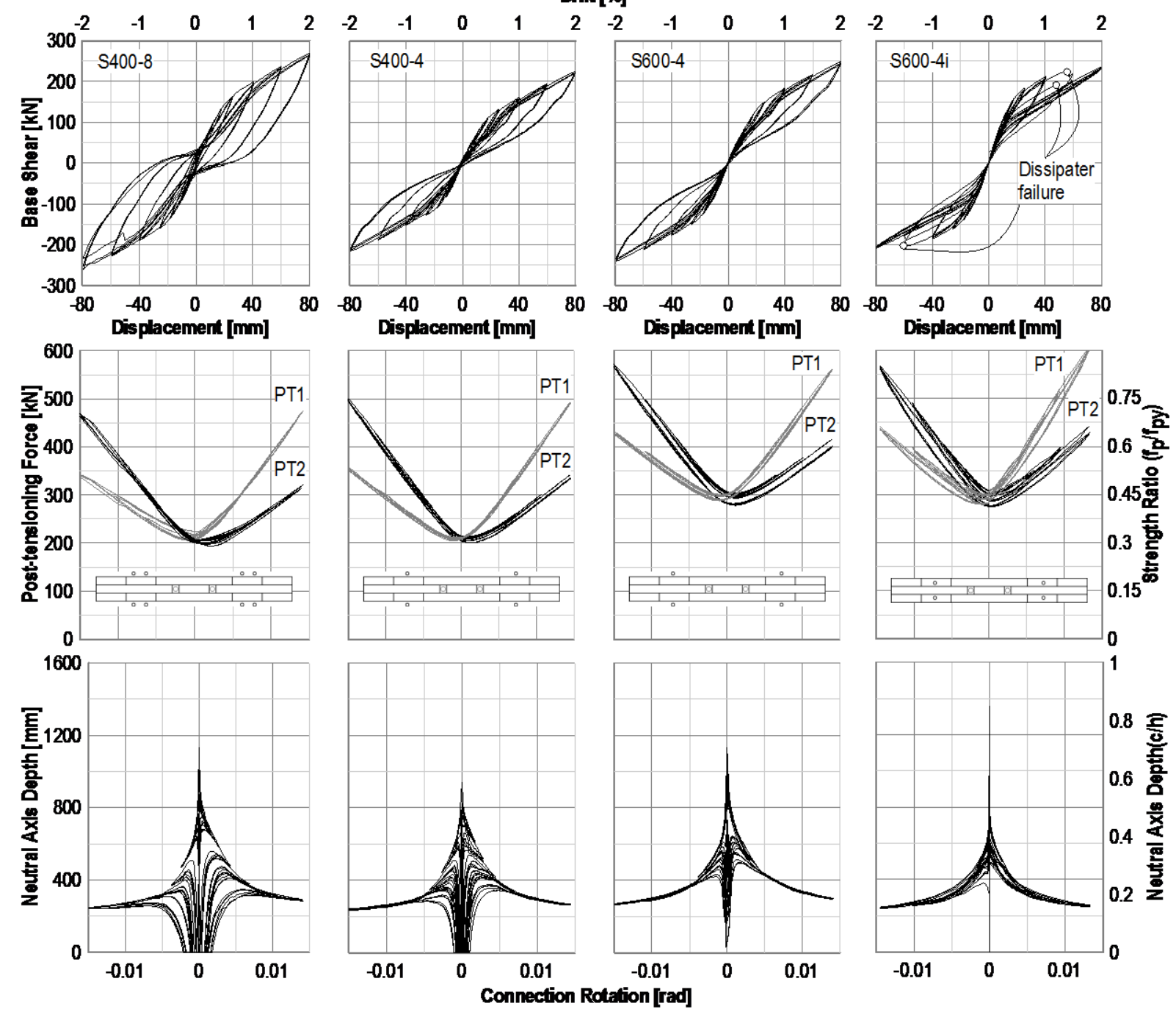

Figure 12. Experimental results. (a) S400-8; (b) S400-4; (c) S600-4; (d) S600-4i.

A closer inspection after testing showed that the edge distance of the internally epoxied dissipater did not provide the necessary buckling restraint; consequently, the dissipaters deformed transversally causing a premature low-cycle fatigue failure. This phenomenon is highlighted in Figure 13 by the out-of-plane deformation and the crack formation observed after testing.

The post-tensioning force and neutral axis depth shown in Figure 12 demonstrate a similar behaviour to that observed in the pure post-tensioning rocking solutions. In particular, the 
initial post-tensioning stress for the specimens tested was in the range $0.3-0.5 f_{\text {py }}$ (see strength ratio on the right axis). This corresponded to an initial timber stress of approximately 1.5$2 \mathrm{MPa}$ (approximately $5 \%$ of the timber compressive strength). This low initial stress level in the timber section results in a smaller neutral axis depth, thus optimizing the system response (i.e. increased tendon elongation and dissipater activation).

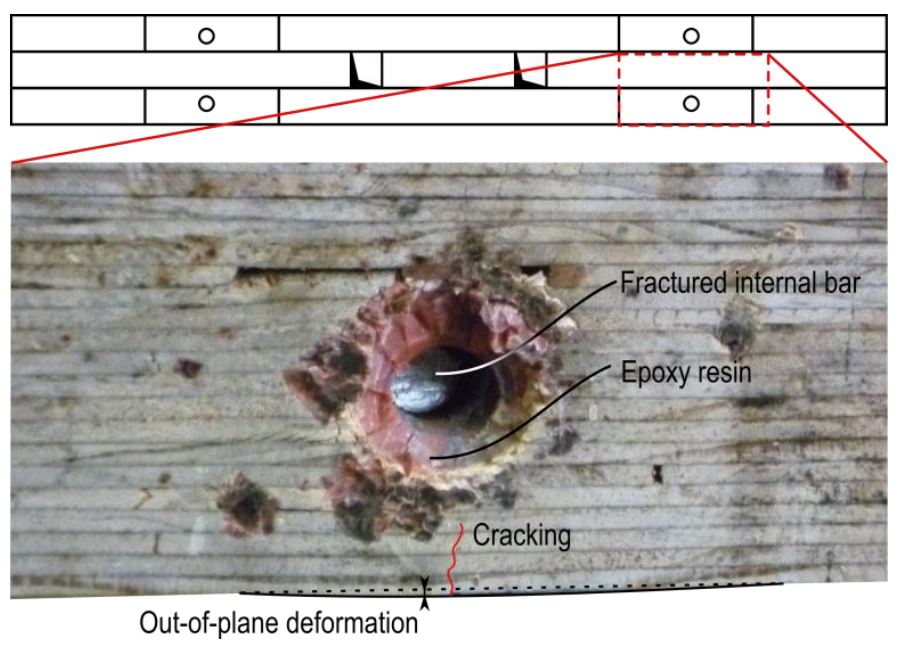

Figure 13. Internal bar out-of-plane behaviour evidence.

\section{Summary of the experimental results}

Table 4 reports a summary of significant parameters for several design limit states. The table contains experimental results in terms of timber and post-tensioning stresses as well as of the average strain in the tension-compression yielding dissipaters, for both internal and external configuration.

As mentioned earlier in this paper, the specimen S600 (i.e. a post-tensioned only solution with $600 \mathrm{kN}$ initial post-tensioning force) displayed some plastic behaviour of the timber section due to high compressive stresses. The maximum stress at MCE demand (2\% drift) approached the nominal timber compressive strength (45MPa).

As expected, the dissipater elongation in the specimen S400-8 was reduced when compared to the 4 dissipater options (S400-4 and S600-4). This effect was due to an increased number of dissipaters for the same connection (i.e. same connection stiffness). When internal bars were used, an increased unbonded length $(300 \mathrm{~mm})$ was adopted since no elastic connection contributions were expected and similar strain values as specimen S600-4 were observed.

Table 4. Experimental data results, summary of maximum significant performance points values.

\begin{tabular}{lccccccccccccccc}
\hline & \multicolumn{4}{c}{ Yield } & \multicolumn{4}{c}{ ULS (1\% drift $)$} & \multicolumn{4}{c}{$M C E(2 \%$ drift $)$} \\
ID & $\mathbf{f}_{\mathbf{p}}$ & $\gamma_{\mathbf{p}}$ & $\mathbf{f}_{\mathbf{t}}$ & $\boldsymbol{\gamma}_{\mathbf{t}}$ & $\boldsymbol{\varepsilon}_{\mathbf{s}}$ & $\mathbf{f}_{\mathbf{p}}$ & $\boldsymbol{\gamma}_{\mathbf{p}}$ & $\mathbf{f}_{\mathbf{t}}$ & $\boldsymbol{\gamma}_{\mathbf{t}}$ & $\boldsymbol{\varepsilon}_{\mathbf{s}}$ & $\mathbf{f}_{\mathbf{p}}$ & $\boldsymbol{\gamma}_{\mathbf{p}}$ & $\mathbf{f}_{\mathbf{t}}$ & $\boldsymbol{\gamma}_{\mathbf{t}}$ & $\boldsymbol{\varepsilon}_{\mathbf{s}}$ \\
& $\mathrm{MPa}$ & - & $\mathrm{MPa}$ & - & - & $\mathrm{MPa}$ & - & $\mathrm{MPa}$ & - & - & $\mathrm{MPa}$ & - & $\mathrm{MPa}$ & - & - \\
\hline S200 & & & & & & 339 & 0.40 & 17 & 0.39 & & 562 & 0.67 & 33 & 0.73 \\
S400 & & & & & & 437 & 0.52 & 20 & 0.45 & & 646 & 0.77 & 35 & 0.79 \\
S600 & & & & & & 539 & 0.65 & 35 & 0.80 & & 747 & 0.89 & 45 & 1.00 \\
S400-8 & 299 & 0.36 & 10 & 0.22 & 0.0029 & 399 & 0.48 & 16 & 0.35 & 0.0190 & 591 & 0.71 & 42 & 0.92 & 0.0549
\end{tabular}


$\begin{array}{llllllllllllllll}\text { S400-4 } & 292 & 0.35 & 8 & 0.17 & 0.0032 & 427 & 0.51 & 19 & 0.42 & 0.0256 & 634 & 0.76 & 41 & 0.90 & 0.0611\end{array}$

$\begin{array}{llllllllllllllll}\mathrm{S} 600-4 & 405 & 0.49 & 15 & 0.33 & 0.0031 & 522 & 0.63 & 20 & 0.45 & 0.0227 & 715 & 0.86 & 35 & 0.77 & 0.0579\end{array}$

\begin{tabular}{llllllllllllllll}
$\mathrm{S} 600-4 \mathrm{i}$ & 396 & 0.47 & 14 & 0.31 & 0.0278 & 526 & 0.63 & 25 & 0.56 & 0.0232 & 755 & 0.90 & 44 & 0.99 & $\mathrm{n} / \mathrm{a}^{*}$ \\
\hline
\end{tabular}

NOTATION: $\mathrm{f}_{\mathrm{p}}=$ maximum post-tensioning stress; $\mathrm{f}_{\mathrm{t}}=$ maximum timber stress; $\varepsilon_{\mathrm{s}}=$ maximum dissipater average strain; $\xi_{\text {hyst }}=$ area-based hysteretic damping; $\gamma_{p}=f_{p} / f_{p y}\left(f_{p y}\right.$ post-tensioning steel yield strength $) ; \gamma_{t}=f_{t} / f_{t y}\left(f_{t y}\right.$ timber yield strength $)$

* Dissipaters failed at $1.5 \% \mathrm{drift}$, hence at MCE drifts the specimen behaved as a post-tensioned only solution

At MCE level, a maximum strain of $6.11 \%$ was measured in the dissipaters, which represents a suggested maximum value to avoid premature low cycle fatigue failure based on extensive experimental tests on tension-compression yield dissipaters (Sarti et al., 2013). When subjected to several reversed cycles most of the dissipaters tested in the wall specimens could withstand the entire loading protocol sequence without failure. Internal bars were an exception and prematurely fractured due to insufficient buckling restrain. To avoid this issue a single line of dissipaters positioned at the centreline of the section could be used.

The experimental results summarized in Table 4 confirmed material limit state values to be adopted in the design phase. In general, the timber stress at the design level (ULS) shall not exceed $40-50 \%$ of the nominal compressive strength and it is expected to reach $70-80 \%$ of the nominal strength at MCE demand. The suggested initial post-tensioning stress in the tendons shall not exceed $0.4-0.5 \mathrm{f}_{\mathrm{py}}$. This upper limit intends to account for the tendon elongation occurring during a seismic event and aims to avoid yielding to the post-tensioning tendons. The dissipaters should be designed to develop a maximum strain at ULS in the range of $2.5-4 \%$, but should be limited to $5-6 \%$ at MCE level. This provides the system with significant ductility and avoids premature low-cycle fatigue failure of the dissipating devices.

\section{Dissipater connection stiffness}

Some instrumentation was used to record the detailed behaviour of the external fuse-type dissipaters. Since the dissipater's yield displacement, thus its activation, is rather small, in the order of $0.4 \mathrm{~mm}$, the stiffness contribution of the connection is a key point of the system behaviour.

The riveted connection was designed using an over-strength factor of 1.5 and assuming that a maximum of three dissipaters were bolted to the connection. The connection used in the test setup, consisting of 12 rows and 6 columns of $90 \mathrm{~mm}$ long timber rivets, had a design capacity $\mathrm{Q}=295 \mathrm{kN}$ (Zarnani et al., 2014).

The estimated connection elastic displacement, $\delta$, can be evaluated using Equation (8) (Zarnani et al., 2014):

$\delta=4\left(1-\sqrt{1-\frac{F}{Q}}\right)$ 
Where $\mathrm{F}$ is the force in the connection and $\mathrm{Q}$ the connection capacity.

Figure 14a shows the dissipater and connection displacement experimental results from the S400-8 specimen. Since the dissipater force could not be directly recorded during testing a force-displacement loop was analytically inferred (Figure 14b). As shown below the inherent flexibility of the connection does not allow the dissipater to return to zero net displacement, causing minor stiffness degradation in the overall force-displacement response (see Figure 14d).

Figure $14 \mathrm{c}$ shows the dissipater force evaluated from analytical relationships against the measured connection relative displacement. It can be seen that the stiffness evaluated from Equation (8), shown in a solid black line, is in good agreement with the experimental data.
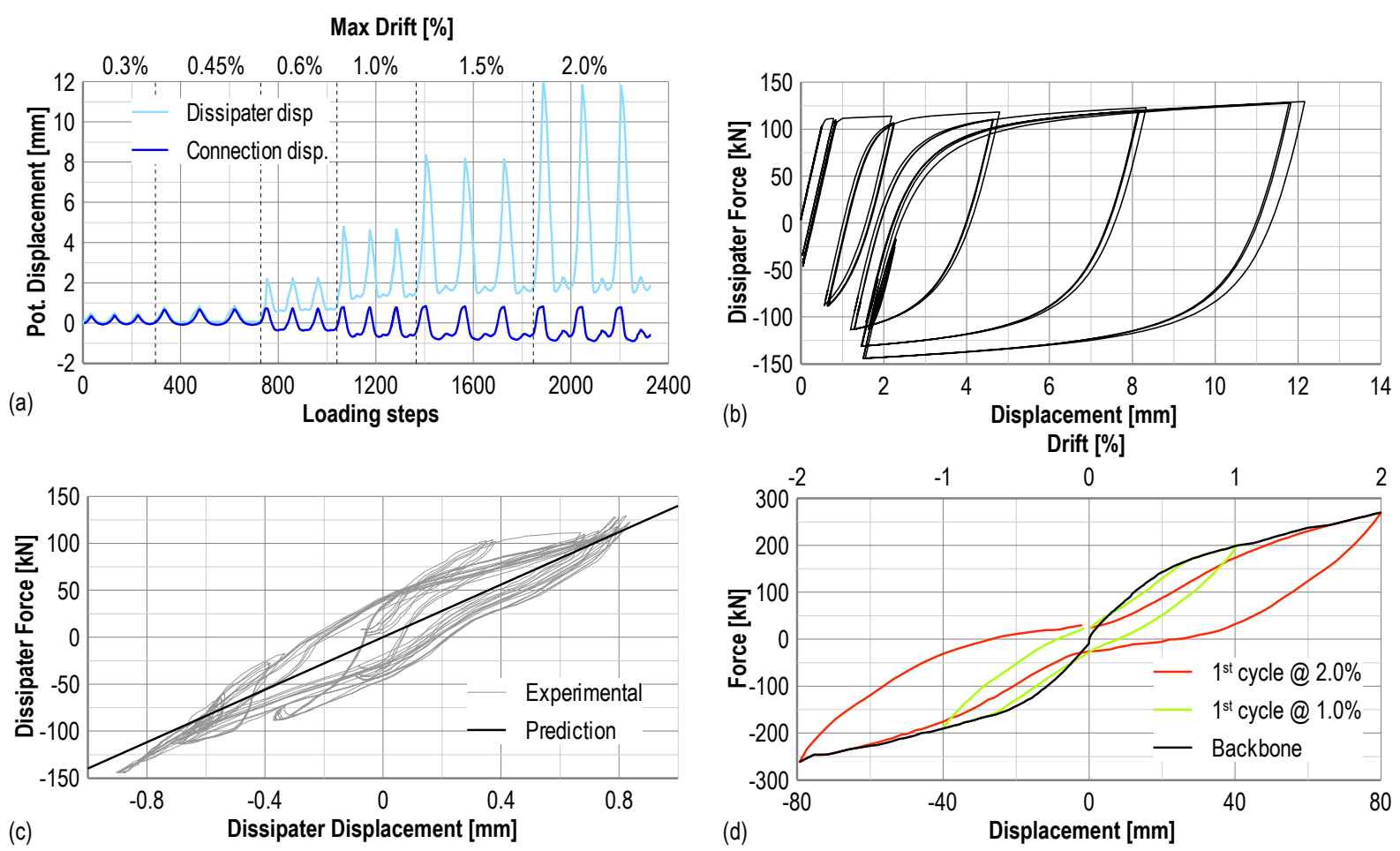

Figure 14. Dissipater connection behaviour (S400-8). (a) Dissipater and connection displacements, (b) dissipater force-displacement loop (numerical from net displacements); (c) connection force-slip diagram; (d) S400-8 force-displacement loop showing the effect of connection stiffness

It can be seen from Figure $14 \mathrm{~b}$ that as soon as the dissipater yields, some residual net displacement of the dissipater occurs. This effect has a direct influence on the overall behaviour of the system, causing some stiffness degradation. This is highlighted by the slightly pinched loop behaviour observed when the specimen is reloaded to the same drift amplitude as shown in Figure 14d.

The connection flexibility also causes an increased ratcheting in the tension-compression dissipater, causing the dissipater to develop lower forces for the same displacement when reloaded (see Figure 14b). 
This issue can be addressed designing either a stiffer riveted connection or using other fastening options (i.e. split-ring, screws).

\section{Area-based equivalent viscous damping}

The area-based equivalent viscous damping (EVD) was evaluated from experimental data using Equation (9).

$$
\xi=\frac{1}{2 \pi} \frac{A_{h}}{F_{m} \Delta_{m}}
$$

Where $A_{h}$ is the area within one complete cycle of stabilized force-displacement response,

$\mathrm{F}_{\mathrm{m}}, \Delta_{\mathrm{m}}$ the maximum force and displacement achieved in the stabilized loops

Priestley et al. (2007) have proposed analytical equations based on an idealized flag-shaped hysteresis.

$$
\xi=\frac{(2-2 \beta)(\mu-1)}{\mu \pi[1+r(\mu-1)]}
$$

Where $\mu \quad=$ ductility

$$
\begin{array}{ll}
\beta & =\text { re-centering ratio }\left(\mathrm{M}_{\mathrm{pt}} / \mathrm{M}_{\mathrm{tot}}\right) \\
\mathrm{r} & =\text { post-yield stiffness factor }
\end{array}
$$

The observed stiffness degradation phenomenon occurred due to the external dissipater connection flexibility. This effect had a more influence on the system behaviour in terms of hysteretic damping. To highlight the magnitude of the reduction of the energy dissipated through hysteresis, the area-based viscous damping was evaluated according to Equation (10) for each cycle of the experimental tests.

As expected, the stiffness degradation was triggered as soon as the dissipaters activated and developed compressive stresses. Experimental observations on area-based EVD values showed a minor degradation from the first to the subsequent cycle at the same amplitude. The area-based EVD reduction was evaluated with reference to the first cycle area-based EVD values evaluated as shown in Figure 15 by the sum of $A_{0}$ and $A_{1}$.

Figure 15a,b also shows the comparison of experimental results with the analytical model of Equation (10) for all the systems tested. The analytical area-based EVD prediction is plotted assuming a constant re-centering ratio (design) value and typically showed an increasing trend, decreasing at higher ductility levels. When compared with the experimental observations, it can be seen from Figure 15 that the analytical model closely predicts the areabased EVD evaluated at the first loading cycle up to design level (1\% drift). However, for higher ductility values Equation (10) underestimates the experimental values. This is due to 
the decreasing of the re-centering ratio at higher drifts caused by isotropic strain hardening in the dissipaters.
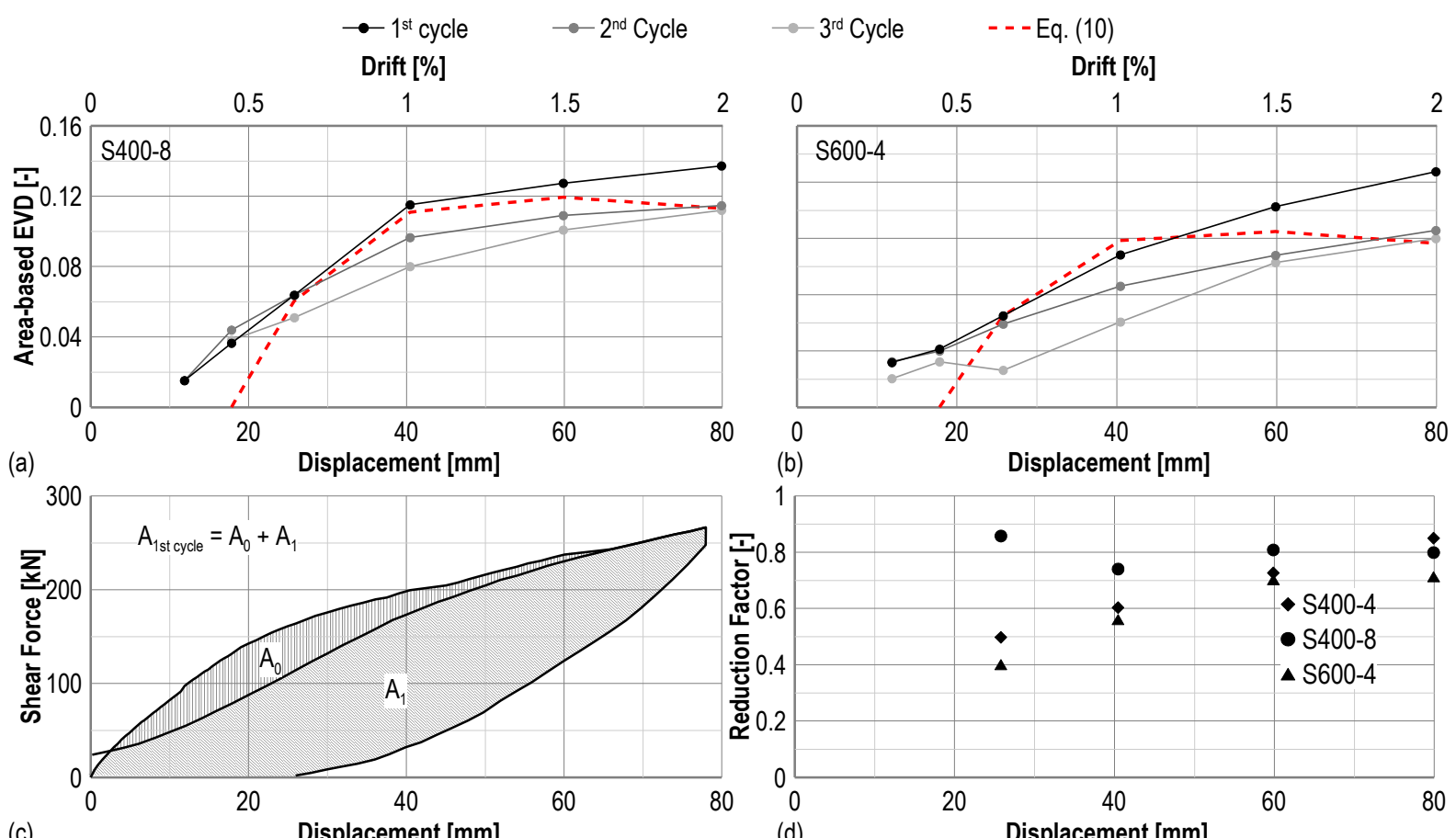

(b) Displacement [mm]

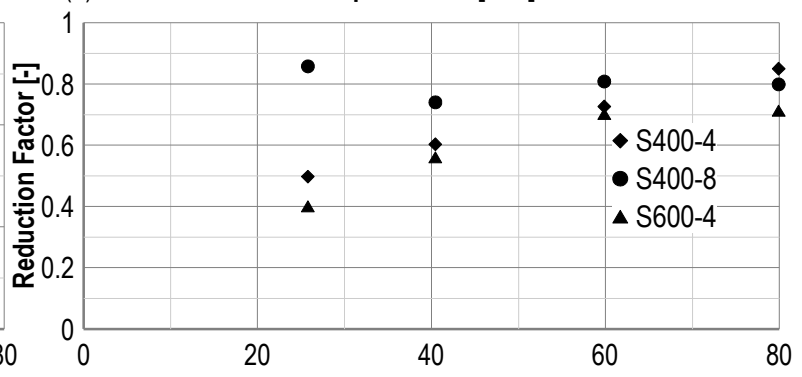

(d)

Displacement [mm]

Figure 15. Experimental equivalent viscous damping of speciments (a) S400-8 and (b) S600-4; (c) Evaluation of area-based EVD;(d) area-based EVD reduction factor.

Based on the experimental observations of the dissipation degrading behaviour of the system from the first to the third cycles, a damping reduction coefficient was evaluated. The reduction factor is given as the ratio of the experimentally evaluated area-based EVD averaged over the three cycles of each amplitude and the area-based EVD value evaluated at the first loading cycle. The different values are plotted in Figure 15 (bottom right) for the different specimens. For the connection used in the experimental program minimum and maximum reduction factors of 0.4 and 0.85 were observed. It must be noted that for low drifts (i.e. low ductility) the experimentally evaluated area-based EVD is strongly influenced by the slip occurring in the experimental setup. Figure 15a,b shows that the minimum and maximum reduction factors for higher drifts (design drift and higher) are approximately 0.55 (S600-4, absolute value 6\%) and 0.85 (S400-8, absolute value 14\%).

This reduction factor can have a significant influence on the lateral load design following a displacement-based design methodology (Priestley et al., 2007). Although an experimental evaluation of the area-based EVD reduction factor was provided in the paper, further numerical work is necessary for a more detailed definition of such a factor. The evaluation of the area-based EVD reduction factor can be achieved using advanced numerical models capable of simulating the rocking mechanisms as well as the behaviour of each system 
component. This can generally investigated using a multi-axial spring model calibrated against the experimental data presented in the paper. A similar approach was developed for post-tensioned precast concrete elements by Spieth et al. (2004) and further validated on precast concrete frame and walls subassemblies by Palermo et al. (2005c).

\section{Conclusions}

The paper reported on the experimental response of a series of post-tensioned timber (Laminated Veneer Lumber) walls, using alternative arrangements of dissipaters and posttensioning level, with particular focus on construction detailing.

The experimental results confirmed the flexibility of the system and all the configurations tested showed excellent performance. Several tests were carried out on the same wall panel and they confirmed that only minor damage occurred to the structural element.

The experimental program showed that the post-tensioning wall system represents a robust solution for resisting seismic actions when properly designed and detailed. This can be achieved by controlling the material stress levels at different performance points. In particular, the post-tensioning bar and timber elements are expected to remain in the elastic range up to MCE levels, while the dissipaters (i.e. the sacrificial elements) are expected to yield and can be expected to fracture for higher demands than ULS.

Testing results highlighted that the connection detailing is crucial to the overall system behaviour. A careful detailing is necessary to minimise the reduction in stiffness resulting from the dissipater's connection displacement. The experimental evaluation of area-based EVD highlighted that this effect caused a reduction of energy dissipation as soon as the dissipaters were activated.

A reduction factor for the area-based EVD has been tentatively proposed based on experimental evidence; further analyses and refinements are required are on-going with the scope to define robust design parameters for direct implementation in a Displacement-Based Design framework.

\section{Acknowledgements}

The experimental program was funded by the Structural Timber Innovation Company (STIC). The technical support of Mosese Fifita and Daniel Moroder is also gratefully acknowledged. 


\section{References}

Aaleti, S., Sritharan, S. 2009. A simplified analysis method for characterizing unbonded posttensioned precast wall systems. Engineering Structures 31(12): 2966-2975.

ACI 318 Committee. 2011. Building Code Requirements for Structural Concrete (ACI 318-11) and Commentary. American Concrete Institute. ACI 318 Committee: 503.

ACI Innovation Task Group 5 2008. Acceptance criteria for special unbonded post-tensioned precast structural walls based on validation testing and commentary : an ACI standard. Farmington Hills, Mich., American Concrete Institute.

Brown, A., Lester, J., Pampanin, S., Pietra, D. 2012. Pres-Lam in practice - A damage-limiting rebuild project. New Zealand Society of Structural Engineers Conference, Auckland, New Zealand.

Buchanan, A., Deam, B., Fragiacomo, M., Pampanin, S., Palermo, A. 2008. Multi-storey prestressed timber buildings in New Zealand. Structural Engineering International 18(2): 166-173.

Buchanan, A.H. 2007. Timber design guide. Wellington, New Zealand, New Zealand Timber Industry Federation.

Chopra, A.K., Goel, R.K. 1999. Capacity-Demand-Diagram Methods Based on Inelastic Design Spectrum. Earthquake Spectra 15(4): 637-656.

Christopoulos, C., Filiatrault, A., Uang, C.M., Folz, B. 2002. Post-tensioned Energy Dissipating Connections for Moment Resisting Steel Frames. Journal of Structural Engineering 128(9): 11111120.

Devereux, C., Holden, T., Buchanan, A., Pampanin, S. 2011. NMIT Arts \& Media Building-Damage Mitigation Using Post-tensioned Timber Walls.

Dunbar, A., Pampanin, S., Palermo, A., Buchanan, A. 2014. Seismic design of core-walls for multistorey timber buildings. New Zealand Society for Earthquake Engineering Annual Conference, Auckland, New Zealand.

Holden, T., Restrepo, J., Mander, J. 2003. Seismic Performance of Precast Reinforced and Prestressed Concrete Walls. Journal of Structural Engineering 129(3): 286-296.

Iqbal, A., Pampanin, S., Buchanan, A.H., Palermo, A. 2007. Improved Seismic Performance of LVL Post-tensioned Walls Coupled with UFP devices. 8th Pacific Conference on Earthquake Engineering, Singapore.

Kam, W.Y., Pampanin, S., Palermo, A., Carr, A.J. 2010. Self-centering structural systems with combination of hysteretic and viscous energy dissipations. Earthquake Engineering \& Structural Dynamics 39(10): 1083-1108.

Kelly, J.M., Skinner, R.I., Heine, A.J. 1974. Mechanism of Energy Absorption in Special Devices for Use in Earthquake Resistant Structures. Bulletin of the New Zealand Society of Earthquake Engineering 5(3): 63-88. 
Kurama, Y., Sause, R., Pessiki, S., Lu, L.-W. 1999. Lateral load behavior and seismic design of unbonded post-tensioned precast concrete walls. ACI Structural Journal 96(4).

Kurama, Y.C. 2000. Seismic design of unbonded post-tensioned precast concrete walls with supplemental viscous damping. ACI Structural Journal 97(4).

Kurama, Y.C. 2002. Hybrid post-tensioned precast concrete walls for use in seismic regions. PCI journal 47(5): 36-59.

Kurama, Y.C., Sause, R., Pessiki, S., Lu, L.-W. 2002. Seismic response evaluation of unbonded posttensioned precast walls. ACI Structural Journal 99(5).

Kurama, Y.C., Shen, Q. 2004. Posttensioned hybrid coupled walls under lateral loads. Journal of structural Engineering 130(2): 297-309.

Macalloy. 2007. European Technical Approval ETA-07/0046. European Organization for Technical Approvals. Charlottenlund, Denmark.

Marriott, D.J., Pampanin, S., Bull, D., Palermo, A. 2008. Dynamic Testing of Precast, Post-Tensioned Rocking Wall Systems with Alternative Dissipating Solutions. Bulletin of the New Zeland National Society for Eartquake Engineering 41(2): 90-103.

Newcombe, M.P., Pampanin, S., Buchanan, A.H. 2010. Design, fabrication and assembly of a twostorey post-tensioned timber building. World Conference on Timber Engineering.

Palermo, A., Pampanin, S., Buchanan, A.H. 2006. Experimental Investigations on LVL seismic resistant wall and frame subassemblies. First European Conference on Earthquake Engineering and Seismology, Geneva, Switzerland.

Palermo, A., Pampanin, S., Buchanan, A.H., Newcombe, M.P. 2005a. Seismic design of multi-storey buildings using laminated veneer lumber (LVL). New Zealand Society of Earthquake Engineering, Annual Conference, Wairakei, New Zealand, University of Canterbury. Civil Engineering.

Palermo, A., Pampanin, S., Calvi, G.M. 2005b. Concept and development of hybrid solutions for seismic resistant bridge systems. Journal of Earthquake Engineering 9(6): 899-921.

Palermo, A., Pampanin, S., Carr, A. 2005c. Efficiency of simplified alternative modelling approaches to predict the seismic response of precast concrete hybrid systems.

Palermo, A., Sarti, F., Baird, A., Dekker, D. 2012. From theory to practice: design, analysis and construction of dissipative timber rocking post-Tensioning wall system for Carterton Events Centre, New Zealand. World Conference on Earthquake Engineering, Lisbon, Portugal.

Priestley, M.J.N., Calvi, G.M., Kowalsky, M.J. 2007. Displacement-based seismic design of structures, IUSS Press.

Priestley, M.J.N., Sritharan, S., Conley, J.R., Pampanin, S. 1999. Preliminary results and conclusions from the PRESSS five-story precast concrete test building. Pci Journal 44(6): 42-+.

Rahman, A.M., Restrepo, J.I. 2000. Earthquake resistant precast concrete buildings: Seismic performance of cantilever walls prestressed using unbonded tendons, Department of Civil Engineering, University of Canterbury. 
Sarti, F., Smith, T., Palermo, A., Pampanin, S., Carradine, D.M. 2013. Experimental and analytical study of replaceable Buckling-Restrained Fused-type (BRF) mild steel dissipaters. New Zealand Society for Earthquake Engineering Annual Conference, Wellington, New Zealand.

Skinner, R.I., Kelly, J.M., Heine, A.J. 1974. Hysteretic dampers for earthquake-resistant structures. Earthquake Engineering \& Structural Dynamics 3(3): 287-296.

Smith, T., Ludwig, F., Pampanin, S., Fragiacomo, M., Buchanan, A., Deam, B., Palermo, A. 2007. Seismic Response of Hybrid-LVL Coupled Walls Under Quasi-Static and Pseudo-Dynamic Testing. NZSEE Conference.

Smith, T., Ponzo, F.C., Di Cesare, A., Pampanin, S., Carradine, D., Buchanan, A.H., Nigro, D. 2013. Post-Tensioned Glulam Beam-Column Joints with Advanced Damping Systems: Testing and Numerical Analysis. Journal of Earthquake Engineering 18(1): 147-167.

Spieth, H.A., Carr, A.J., Pampanin, S., Murahidy, A.G., Mander, J.B. 2004. Modelling of Precast Prestressed Concrete Frame Structures with Rocking Beam-Column Connections. Technical report Report 2004-01. Christchurch, New Zealand, University of Canterbury.

Standards New Zealand 2004. AS/NZS 1170.5: Structural Design Actions - Part 5: Earthquake actions.

Standards New Zealand. 2006. Concrete structures standard. NZS 3101. Standards New Zealand. Wellington, New Zealand, Standards New Zealand.

STIC. http://www.stic.co.nz

Stone, W.C., Cheok, G.S., Stanton, J.F. 1995. Performance of hybrid moment-resisting precast beamcolumn concrete connections subjected to cyclic loading. ACI Structural Journal 92(2).

Zarnani, P., Quenneville, P. 2014. Strength of timber connections under potential failure modes: An improved design procedure. Construction and Building Materials 60(0): 81-90. 